
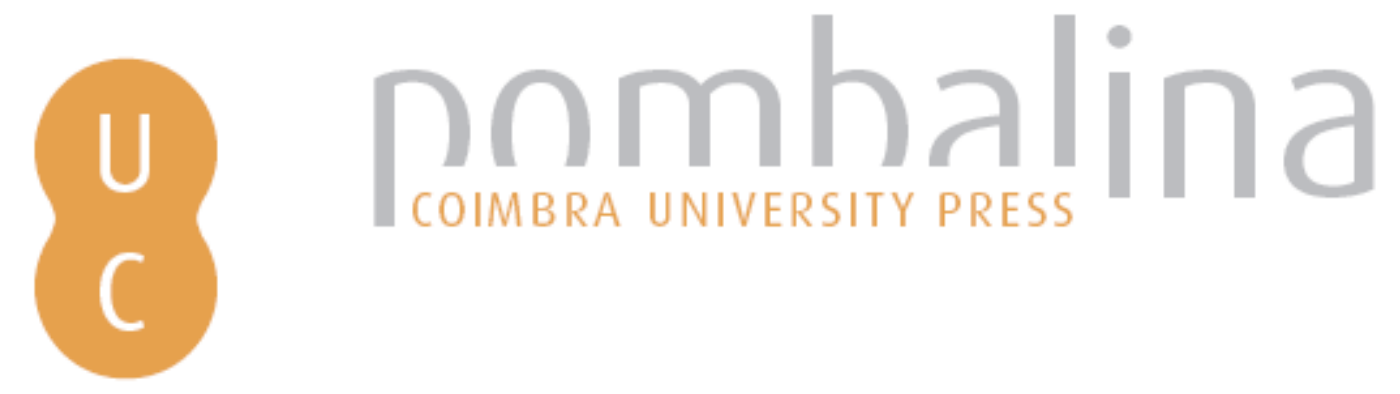

\title{
Variation in peatland wildfire severity - implications for ecosystem carbon dynamics
}

Autor(es): $\quad$ Davies, G. Matt; Gray, Alan; Jardi, Ruth Domenech; Johnson, Paul

Publicado por: Imprensa da Universidade de Coimbra

URL

persistente:

URI:http://hdl.handle.net/10316.2/34204

DOI:

DOI:http://dx.doi.org/10.14195/978-989-26-0884-6_68

Accessed : $\quad$ 26-Apr-2023 12:26:57

A navegação consulta e descarregamento dos títulos inseridos nas Bibliotecas Digitais UC Digitalis, UC Pombalina e UC Impactum, pressupõem a aceitação plena e sem reservas dos Termos e Condições de Uso destas Bibliotecas Digitais, disponíveis em https://digitalis.uc.pt/pt-pt/termos.

Conforme exposto nos referidos Termos e Condições de Uso, o descarregamento de títulos de acesso restrito requer uma licença válida de autorização devendo o utilizador aceder ao(s) documento(s) a partir de um endereço de IP da instituição detentora da supramencionada licença.

Ao utilizador é apenas permitido o descarregamento para uso pessoal, pelo que o emprego do(s) título(s) descarregado(s) para outro fim, designadamente comercial, carece de autorização do respetivo autor ou editor da obra.

Na medida em que todas as obras da UC Digitalis se encontram protegidas pelo Código do Direito de Autor e Direitos Conexos e demais legislação aplicável, toda a cópia, parcial ou total, deste documento, nos casos em que é legalmente admitida, deverá conter ou fazer-se acompanhar por este aviso. 


\section{ADVANCES IN}

Forest Fire

\section{RESEARCH}

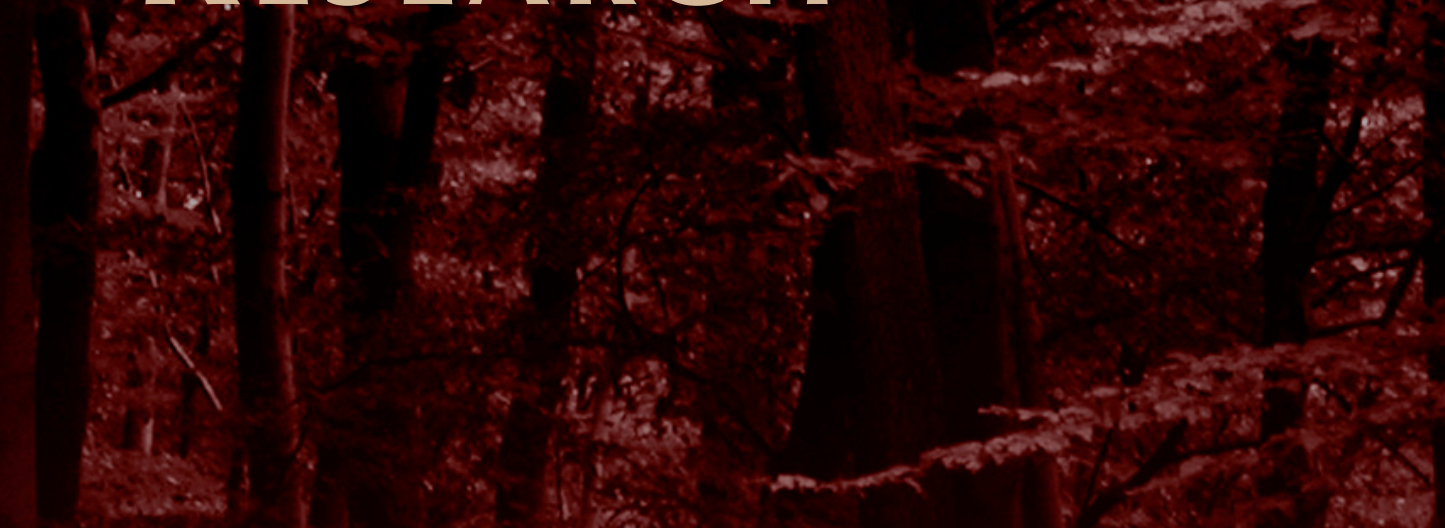

\section{DOMINGOS XAVIER VIEGAS}

\section{EDITOR}




\title{
Variation in peatland wildfire severity - implications for ecosystem carbon dynamics
}

\author{
G. Matt Davies ${ }^{\mathrm{a}}$, Alan Gray ${ }^{\mathrm{b}}$, Ruth Domenech Jardic, and Paul Johnson ${ }^{\mathrm{d}}$ \\ ${ }^{a}$ Solway Centre for Environment and Culture, University of Glasgow, Dumfries, DG1 4ZL, UK, \\ gwilym.davies@glasgow.ac.uk \\ ${ }^{b}$ Centre for Ecology and Hydrology, Bush Estate, Penicuik, Midlothian, EH26 0QB, UK, \\ alangray@ceh.ac.uk \\ ${ }^{c}$ Solway Centre for Environment and Culture, University of Glasgow, Dumfries DG1 4ZL, UK, \\ rdomenja@yahoo.es \\ ${ }^{d}$ Institute of Biodiversity, Animal Health and Comparative Medicine, University of Glasgow, \\ Glasgow,G128QQ,paul.johnson@glasgow.ac.uk
}

\begin{abstract}
Globally peatlands contain ca. 550 GT of ancient carbon and there is the potential for a positive feedback between peatland degradation and global climate change. Peatlands cover a substantial area of the British Uplands and the effects of wildfire and traditional managed burning on their ecological integrity are issues of growing debate. Land-managers and conservationists continue to argue over the effects of managed and wild fire on peatland carbon dynamics. Clear differences do exist in the severity of moorland fires and wildfires, though often intense, are not necessarily severe. The aim of our project was to document variation in the severity and ecological effects of a spate of peatland wildfires that burnt during the springs of 2011 and 2012. We identified a number of fire locations that included coverage of variation in major north-south and east-west bioclimatic conditions and peatland types. Fire severity was described using a modified form of the semiquantitative Composite Burn Index. Fuel consumption was assessed using destructive harvesting of burnt- and unburnt fuel loads. Carbon dioxide and methane fluxes were assessed using samples taken from gas flux chambers. Fire severity varied substantially both within and between individual fires. Average severity varied up to two-fold between fires but as much as three-fold within some fires. Total carbon loss varied substantially between and within wildfires. Average fire-level consumption was $0.64 \pm 0.12 \mathrm{~kg} \mathrm{C} \mathrm{m}^{-2}$ but this estimate should be treated with caution. Consumption was best described by a mixed effects model than included random intercepts for different fires and plots within fires and random slopes for different plots. The evidence for differences in consumption between fires was weak due to the small sampling size and the substantial within plot and fire variation in fuel load. There was a linear relationship between pre-fire fuel surface load and surface fuel consumption but no obvious difference between the prescribed and wild fires in how the proportion of fuel consumed changed with increasing fuel load. Soil methane fluxes were consistently lower on burnt sites whilst carbon dioxide fluxes were generally higher. Day-night temperature fluctuations in burnt plots were frequently more than twice that seen in unburnt plots. Our results demonstrate substantial variation in fire severity both within and between individual wildfire events. Assessment of the effects of wildfires requires intensive sampling efforts and drawing robust conclusions about the implications of wildfire on ecosystem $\mathrm{C}$ dynamics is thus fraught with difficulties.
\end{abstract}

Keywords: carbon dioxide, Composite Burn Index, fuel consumption, methane, soil gas flux, soil microclimate

\section{Introduction}

Globally peatlands contain ca. $550 \mathrm{GT}$ of ancient carbon (Mitra et al. 2005) but there is considerable concern about the potential for a positive feedback between peatland degradation and global climate change (Turetsky et al. 2002, Dorrepaal et al. 2009). Many temperate and boreal peatlands experience wildfires and when these fires ignite peat deposits substantial amounts of carbon can be released (e.g. Davies et al. 2013). Ecosystem recovery following such severe burns can be extremely slow due to 
the destruction of below-ground plant propagules (Granström and Schimmel 1993). More pernicious fire effects, such as scorching of the peat surface or removal of ground fuel layers overlying peat deposits, are also possible but the ecosystem implications of such impacts are relatively poorly-studied. The results of Maltby et al. (1990) however suggest that ecosystem recovery in such cases can take decades or longer. Little quantitative evidence exists of the extent to which peatland wildfire severity varies, the fuel and fire weather drivers of variation in severity or the ecological impacts of such variation.

Peatlands cover a substantial area of the British Uplands and the effects of wildfire and traditional managed burning on their ecological integrity are issues of growing debate (Davies et al. 2008a). Fire is an integral part of the traditional management of heaths and moorlands and is used to create a diversity of heather (Calluna vulgaris, hereafter Calluna) dominated habitat structures that support large surplus populations of red grouse (Lagopus lagopus scoticus) for hunting (Tharme et al. 2001). Traditional burning also provides fresh growth of heather for sheep and deer grazing (Smith and Thomas 1956), creates habitats for rare wildlife (Tharme et al. 2001) and may help to manage fuel loads reducing the potential for large or severe wildfires (Davies et al. 2008a). Nevertheless, landmanagers and conservationists continue to argue over the effects of fire on peatland habitat structure, biodiversity and soil carbon dynamics. With regards to the latter there remains rather little scientific information to inform best-practice fire management (Blodau 2002).

Relatively few studies have directly examined the effects of fire on soil carbon fluxes or hydrology in U.K. peatlands. For the studies that do exist, most come from a single long-term experiment at Moor House in northern England. Here Ward et al. (2007) recorded increased net ecosystem respiration and reduced methane emissions as a result of burning. Additionally, Worrall et al. (2007) observed higher water tables in plots subject to more frequent managed burns. A larger number of studies have examined the effect of fire on the production of dissolved organic carbon though the results remain difficult to interpret and somewhat controversial. Holden et al. (2012) point to discrepancies between plot and catchment scale experiments and suggest that the results of catchment scale studies showing increased DOC production (e.g. Clutterbuck and Yallop 2010) should be treated with some caution.

Clear differences do exist in the severity of moorland fires and we can distinguish between high severity burns, that consume surface and ground fuels, whilst igniting or scorching underlying peat (e.g. Maltby et al. 1990) and lower severity prescribed burns that have more limited ecosystem effects (Davies et al. 2010). However, wildfires, though often intense, are not necessarily severe (Bullock and Webb 1995). There is thus a clear need to describe the extent to which fire severity varies in peatland ecosystems and to understand what processes drive this variation. During the springs of 2011 and 2012 a large number of intense and severe wildfires burnt across heaths and moorlands throughout the UK. The extent of these fires, associated environmental degradation and the costs of restoration have added to increasing concern about potential feedbacks between climate, fire frequency, fire severity and carbon fluxes from moorlands (e.g. Davies et al. 2008a). Research on the impacts of such fires on UK peatlands is urgently needed to inform the development of fire danger rating systems (e.g. Kitchen et al. 2006) and to fill fundamental knowledge gaps regarding fire, peatland and global change.

The aim of our project was to document variation in the severity and ecological effects of a spate of peatland wildfires that burnt during the springs of 2011 and 2012. Here we report the results of preliminary analyses of variation in i) peatland fire severity; ii) carbon lost from direct combustion of above-ground biomass and iii) changes in methane and carbon dioxide fluxes following burning.

\section{Methods}

\subsection{Study sites}

Though regional Fire and Rescue Services collect some data on the occurrence of wildfire there is currently no national system in place for reporting wildfire outbreaks. We therefore worked in collaboration with land management agencies, land owners and other stakeholder groups to identify a 
number of fire locations that included coverage of variation in major north-south and east-west bioclimatic conditions and peatland types (Figure 1).

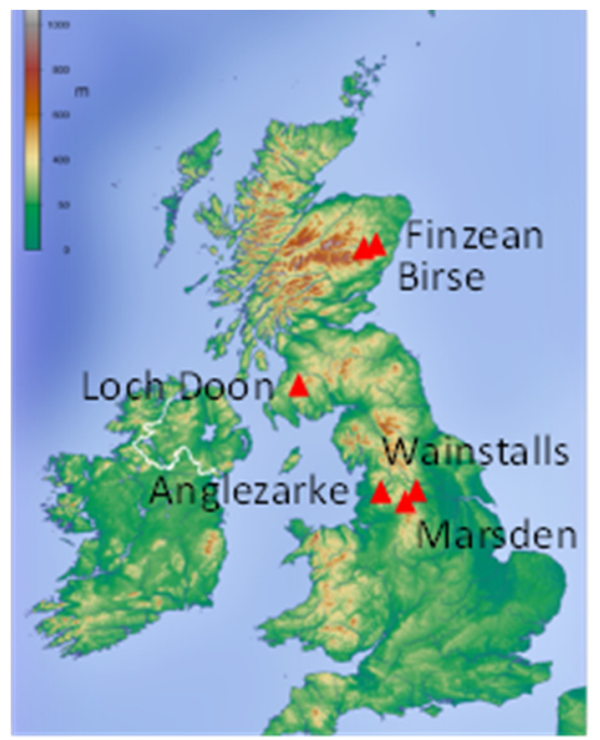

Figure 1. Location of wildfire study sites across the U.K. Sites covered a range of bioclimatic conditions and included fires in dry heath communities on shallow, stony organic soils (Finzean, Birse), active blanket bogs dominated by Molinia caerulea and Sphagnum spp. (Loch Doon) as well as wet and dry Calluna- and grass/sedge dominated moorland on peat soils (Angelzarke, Wainstalls, Marsden).

Each wildfire was assessed using a walk-over survey with the relevant land-owner. We created or obtained maps of the fire perimeter and carefully noted qualitative evidence of variation in fire severity. In each fire we selected three to six locations for further monitoring that best represented the range of severities we observed.

\subsection{Monitoring fire severity}

Fire severity was described using a modified form of the semi-quantitative Composite Burn Index (CBI; Key and Benson 2006). This method was adapted for use on treeless moorlands and bogs similarly to Schepers et al. (2014). The CBI uses qualitative descriptions of fire effects on a number of vegetation strata and ecosystem properties each scored on a rating of zero to three. These scores are then averaged within strata and the averages summed across strata to produce an overall severity index. Our method included assessment of fire effects on surface and ground fuel layers. We thus examined: litter/ light fuel consumption, duff/peat consumption, exposure of mineral soil, damage or loss of Sphagnum capitula, moss scorching and consumption, recovery of Sphagnum/moss species, percentage of shrubs top-killed, fine/crown fuel consumption, frequency of burnt shrubs or grass/sedge tussocks resprouting, evidence of new colonizers and the potential for changes in species composition.

CBI plots were circular, $20 \mathrm{~m}$ in diameter and established both as stand-alone plots in the fire interior and as paired burnt/unburnt plots close to the fire perimeter (Figure 2). For paired plots, we avoided edge-effects by ensuring the burnt plot centre was always located $<30 \mathrm{~m}$ from the edge of the fire. No part of any plot was $<5 \mathrm{~m}$ from the fire perimeter or, for unburnt plots, in obviously scorched vegetation. We were careful to ensure that burnt and unburnt plots had similar pre-fire fuel structures by locating them in the same pre-fire Calluna stand through careful observation of stem density and basal diameters either side of the fireline. Due to the large size of the wildfires, the substantial spatial separation of the plots and variation in pre-fire fuel structure we considered each CBI plot or pairedplot to be an independent observation in a manner similar to the "microplot" approach of Fernandes $e t$ al. (2000). 


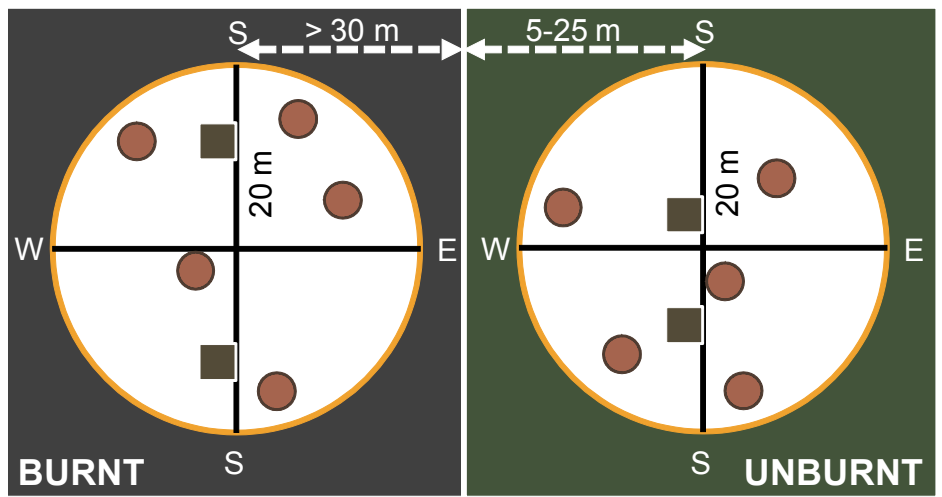

Figure 2. Layout of CBI monitoring plots showing the two fuel quadrats (squares), located at random distances along the N-S axis, and five soil gas flux chambers (circles) located at random co-ordinates in each plot

\subsection{Variation in above ground carbon loss}

Fuel consumption was assessed using destructive harvesting of fuel loads in two $50 \times 50 \mathrm{~cm}$ quadrats located at random co-ordinates within the paired burnt/unburnt plots (two paired plots per fire). All above ground biomass was harvested down to the top of the peat. We harvested surface fuels (shrubs, grasses, etc.) separately from ground fuels (Sphagnum spp., other mosses + plant litter, grass/sedge tussock bases and duff). Fuel was also harvested in a similar manner from five gas flux chambers (diameter $=38 \mathrm{~cm}$; see below) located at random locations throughout each plot. Samples were processed in the lab and dried at $80^{\circ} \mathrm{C}$ for 48 hours before being weighed. Fuel consumption was defined as average unburnt plot biomass minus average burnt plot biomass. Combustion completeness was defined as the proportion of fuel consumed and above-ground carbon loss was estimated by assuming all fuel components had a C proportion of 0.48 (Legg et al. 2010). We compared consumption and combustion completeness of our wildfires with data from 26 prescribed fires described by Davies et al. (2009). This comparison was however limited to changes in surface fuels (herbaceous and shrub species) as data on consumption of ground fuels were limited for the prescribed burns.

Total fuel consumption (i.e. all fuel components pooled) was analysed by making a square root transformation of the data and using a General Linear Mixed Model in the "lme4" package (Bates et al. 2013) of $\mathrm{R} 2.15 .0$ (R Development Core Team 2012). Plot and fire were defined as random effects whilst status (burnt/unburnt) and sample (chamber/quadrat ID) were defined as fixed effects. We initiated analysis using the full model (random slopes, according to status, and intercepts) and simplified the model by reference to AIC. Parametric bootstrapping was used to fit $95 \%$ confidence intervals around mean fire-level fuel consumption that accounted for uncertainty due to sampling variation in quadrats/chambers and plots.

\subsection{Assessing soil carbon fluxes}

Carbon dioxide and methane fluxes were assessed using samples taken from five gas flux chambers permanently located at random co-ordinates within each side of our burnt/unburnt plot pairs (Figure 2). The chambers were made of black plastic, had a diameter of ca. $38 \mathrm{~cm}$ and a volume of ca. 301 . Chamber bases were buried $3-5 \mathrm{~cm}$ below the top of the peat. We made five measurements of the distance from the chamber top to the internal ground level in order to determine the installed chamber volume. As we were interested in variation in fire effects on the soil ecosystem we chose to contrast carbon fluxes in our burnt plots with a "zero severity burn" in the unburnt plot and in the absence of plant photosynthesis and respiration. This was achieved by removing all vegetation (surface and ground fuels) in the chambers down to the top of the peat. Any variation in flux was thus solely a result of varying fire effects on the soil. We acknowledge that the removal of vegetation can cause changes 
in the production of root exudates which might alter the structure and activity of soil microbial communities. However, since the above ground components of plants were removed in both burnt and unburnt plots, we suggest any difference should be attributable to temperature pulses from the fire, scorching or heat induced alteration of peat structure. Chambers were sealed using metal lids and gas samples extracted using a syringe. The sample was then used to fill an airtight vial. Samples were extracted immediately following closure and at ten minute intervals thereafter to produce a total of five samples per chamber. Methane and carbon dioxide concentrations were analysed using a gas chromatograph and fluxes estimated by standard regression-based methods.

Due to the importance of soil temperature in determining peatland soil carbon fluxes (e.g. Updegraff et al. 2001) we buried iButton ${ }^{\mathrm{TM}}$ temperature loggers $2 \mathrm{~cm}$ below the top of the peat (and thus below overlying layers of moss, litter and duff in unburnt plots) in a random subsample of our paired plots. Two loggers were buried in each plot - one each in the burnt and unburnt subplot. Loggers recorded soil temperature hourly and were left in place for up to a month and half during August and September.

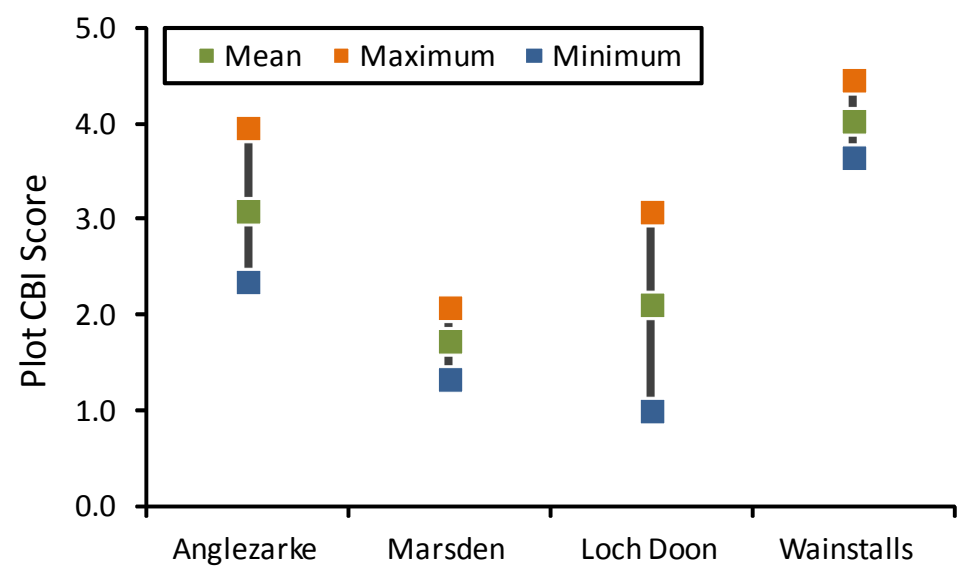

Figure 3. Variation in fire severity between and within four wildfires (data for Finzean to be analysed). Symbols show fire mean (green), minimum (blue) and maximum (orange) Composite Burn Index score.

\section{Results}

\subsection{Variation in fire severity}

Fire severity varied substantially both within and between individual fires. Interestingly average severity varied up to two-fold between fires but as much as three-fold within some fires (Figure 1).

\subsection{Variation in above ground carbon loss}

Total carbon loss varied substantially between and within wildfires (Figure 4) but average fire-level consumption was $0.64 \pm 0.12 \mathrm{~kg} \mathrm{C} \mathrm{m}^{-2}$ across the five wildfires we studied. Average fire-level losses were relatively consistent with the exception of Finzean. Here mean carbon losses were both notably higher than other fires and the amount of variation between plots rather small. 


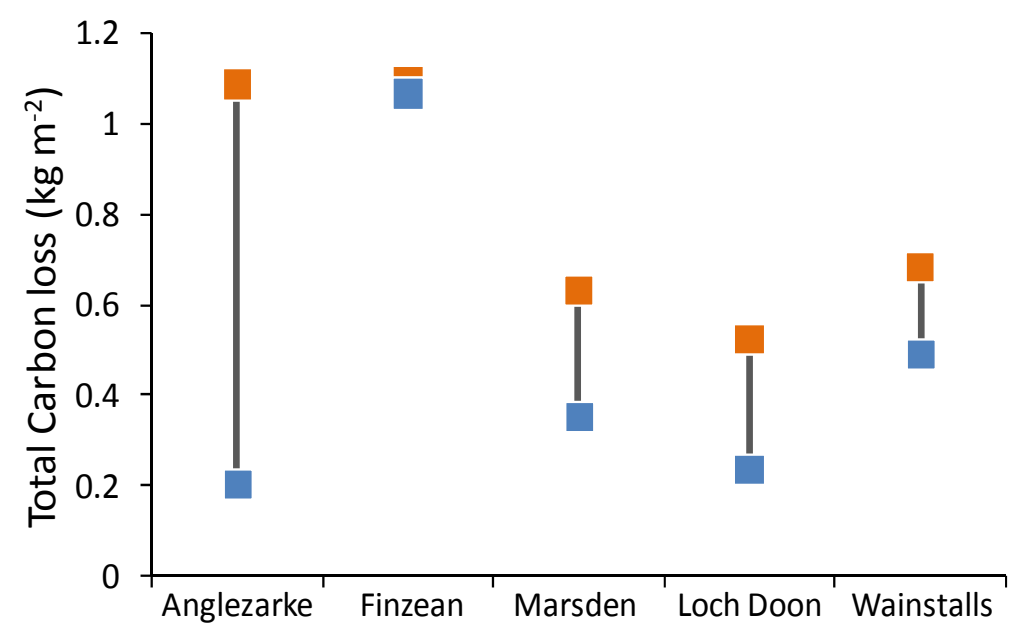

Figure 4. Variation in total (ground and surface fuels) carbon loss due to combustion across five wildfires. Blue and orange points are the minimum and maximum losses recorded respectively.

Fuel consumption was best described by a model than included the fixed effects of plot status (burnt/unburnt), quadrat ID and random intercepts for different fires and plots within fires and random slopes for different plots. The evidence for differences between fires was weak but was retained in the model as the relatively small sample size meant such differences couldn't be categorically discounted. Consumption thus varied substantially between plots within fires but there was limited evidence of a difference in average consumption between fires (Figure 2). Parametric bootstrapping was used to fit $95 \%$ confidence intervals and revealed substantial uncertainty in the prediction of mean fire fuel consumption due to sampling variation in quadrats/chambers and plots (Figure 2).

There was a linear relationship between pre-fire surface fuel load and surface fuel consumption but no obvious difference between the two types of fire in how the proportion of fuel consumed changed with increasing fuel load (Figure 6). Surface fuel consumption increased linearly with increasing fuel load up to a load of ca. $1.25 \mathrm{~kg} \mathrm{~m}^{-2}$, thereafter fuel consumption appeared to reach an asymptote. This was reinforced by the apparent decline in combustion completeness with increasing fuel load. It was noticeable that the surface fuel load of the prescribed fires was, on average, higher than that found on the wildfire sites we monitored.
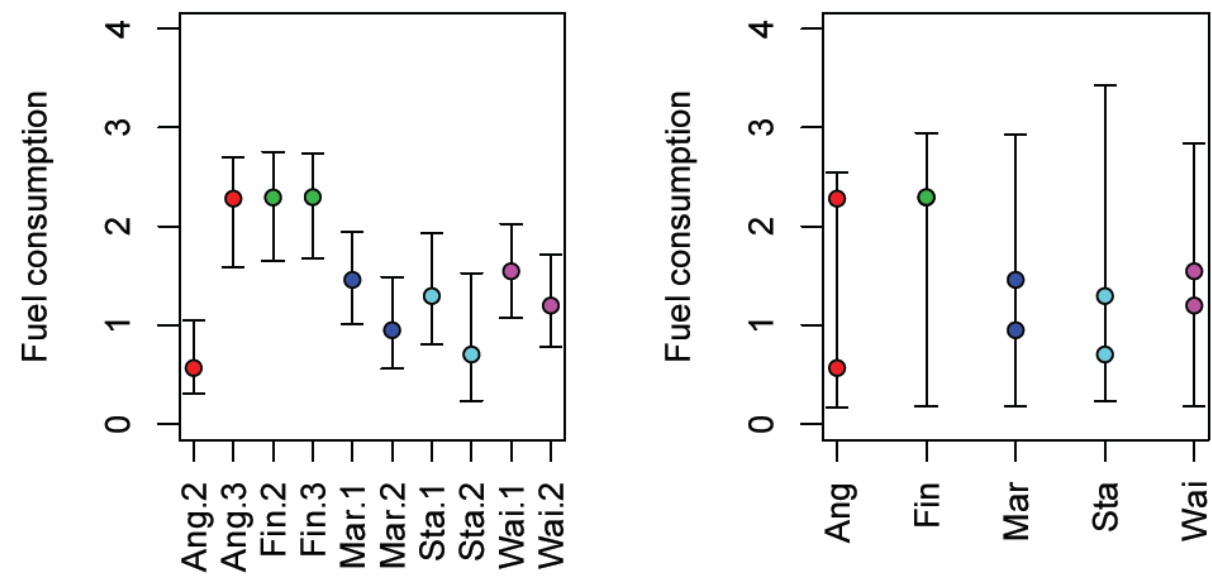

Figure 5. variation in total fuel consumption $(\mathrm{kg} / \mathrm{m} 2)$ between and within five different wildfires (left). Bootstrapped 95\% Confidence Intervals showing uncertainty in fire mean fuel consumption due to within plot and within fire variation in fuel load (right). 

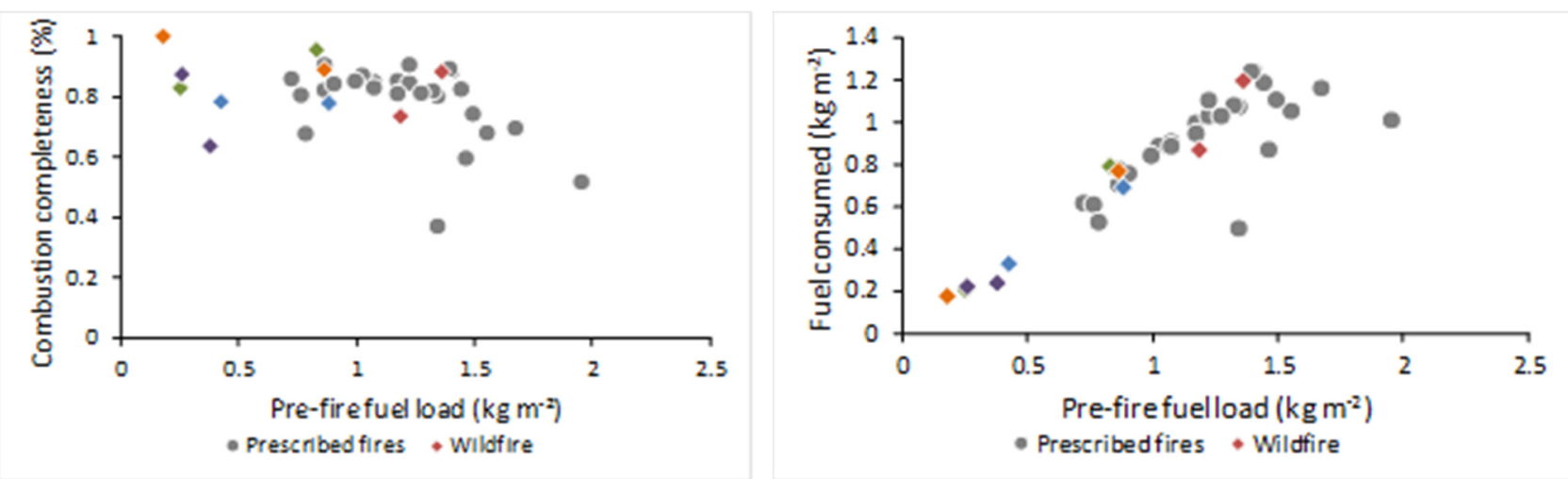

Figure 6. The relationship between pre-fire surface (herbaceous and shrub) fuel load and combustion completeness (left), and fuel consumption (right) for five wildfires (diamonds) and the 26 prescribed burns (grey circles) described by Davies et al. (2009). For wildfires each point is a CBI paired plot rather than a fire per se. Colours define each wildfire - Angelzarke (green), Finzean (red), Loch Doon (purple), Marsden (orange) and Wainstalls (blue). Note that for clarity errors are not shown here but they are likely to be large (see Figure 5)

\subsection{Variation in soil gas fluxes}

Both $\mathrm{CO}_{2}$ and $\mathrm{CH}_{4}$ fluxes were noticeably different between burnt and unburnt plots but substantial differences also existed between different fires. Methane fluxes were consistently lower on burnt sites whilst carbon dioxi
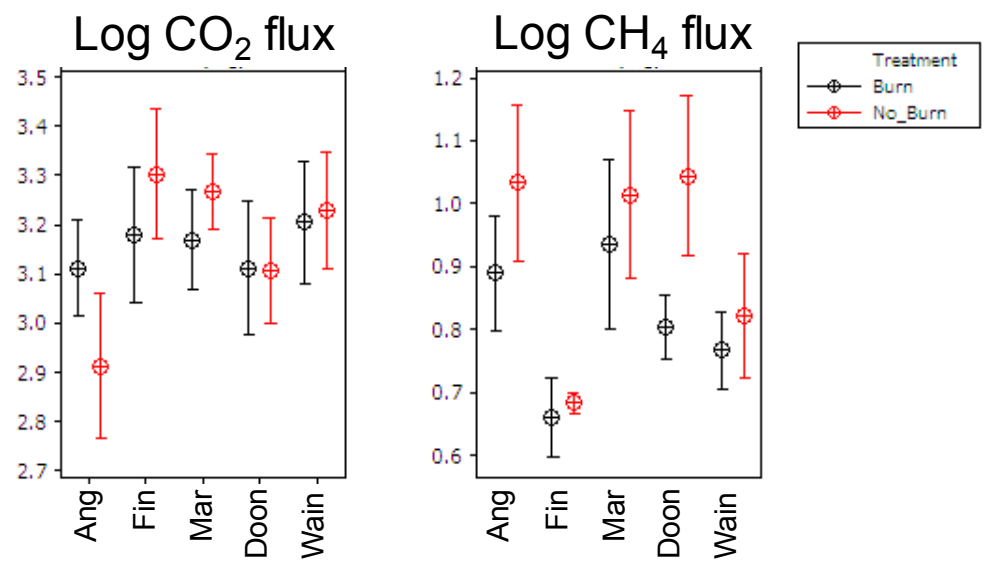

Figure 7. Variation in mean carbon dioxide (left) and methane (right) fluxes recorded in paired burnt/unburnt CBI plots across five different wildfire sites.

Substantial differences were recorded in both mean soil temperature and diurnal temperature trends between brunt and unburnt plots. Day-night temperature fluctuations in burnt plots were frequently more than twice that seen in unburnt plots (Figure 8). 

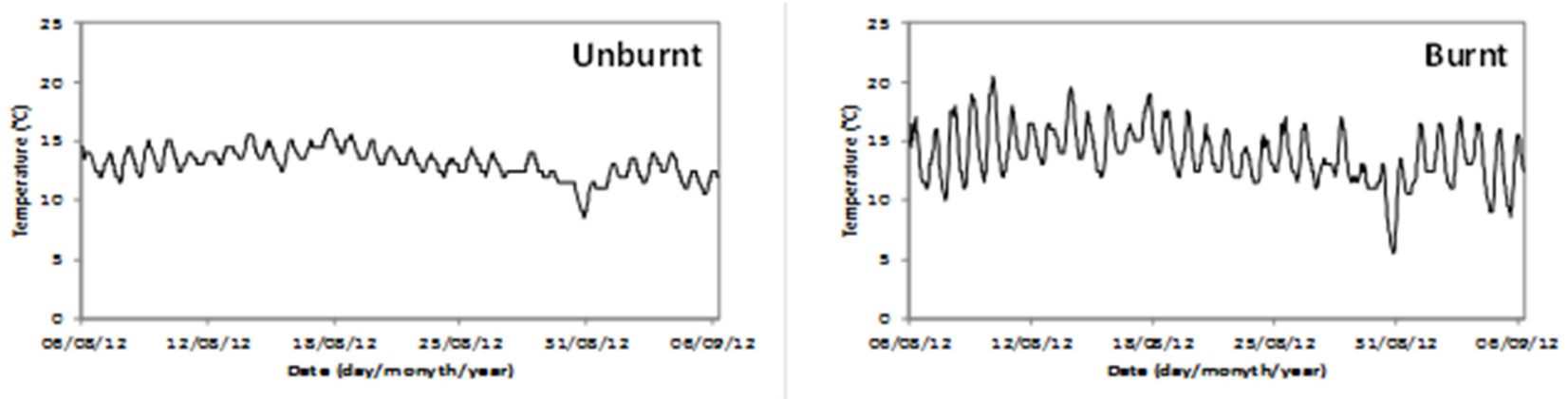

Figure 8. Example of typical patterns of diurnal soil temperature variation in unburnt and burnt plots

\section{Discussion}

Our results demonstrate substantial variation in fire severity both within and between individual wildfire events (Figure 4). Given the potential for substantial variation in fuel structure (Davies et al. 2008b) and fire weather (Legg et al. 2007) in the British uplands this is perhaps not surprising. A key finding of our work is therefore that robust assessment of the effects of wildfires requires substantial sampling effort. Variation in CBI and our estimates of fuel consumption were greater within a number of fires than that recorded, on average, between different burns. Managers needing to understand the effects of wildfires on landscapes, or researchers and policy makers wanting to quantify the effects of burning on landscape $\mathrm{C}$ storage, must therefore ensure that their monitoring is representative of this variation. Despite investing substantial monitoring effort in assessing fuel structure in burnt and unburnt stands the variation in fuel load encountered at both the sub-plot and fire levels mean we were unable to draw any robust conclusions about differences in consumption between fires (Figure 5). It is also clear that the estimate of mean carbon released by combustion we present should be treated with caution.

Though our monitoring captured a range of fuel structures it was clear from comparison with data from prescribed burns that this did not adequately reflect the range of fuel loads found on British peatlands (Figure 6). Broad differences in fuel consumption between and within wildfires could generally be related to pre-fire fuel composition. High levels of combustion completeness were recorded across all sites but this tended to be lower on wetter sites like Loch Doon. In such bog communities strong vertical gradients in the moisture content of standing Molinia litter may limit fuel consumption (Hamilton 2000). Prescribed fires in Calluna-dominated fuels generally consume all fine fuels $<$ ca. 2 $\mathrm{mm}$ in diameter leaving behind larger, live woody stems (Davies 2006). This relationship is apparent in Figure 6 where the asymptote in fuel consumption as a function of fuel load is a consequence of the higher proportion of coarse, woody fuels in these older stands. In very severe burns this woody material may also be consumed but, the relationship we observed between pre-fire fuel load and fuel consumption (Figure 6) suggests that carbon release from the direct combustion of surface fuels only can be predicted from pre-fire fuel load for all but the most severe fires. Further analysis is needed to allow for comparison of consumption of ground fuels during prescribed burns and wildfires, and on fuel consumption during higher severity wildfires. This will allow us to determine whether, or under what burning conditions, differences in combustion processes operate and lead to altered rates of $\mathrm{C}$ emission.

For fires that do not lead to consumption or scorching of ground fuel layers and peat the carbon lost from combustion should, in theory, be of comparatively little concern. Calluna and other moorland plants such as Molinia and Erica spp. are able to regenerate rapidly both from seed and vegetatively (e.g. Hobbs and Gimingham 1984, Davies et al. 2010). Regeneration may, however, be delayed, lacking or follow alternative successional trajectories in older stands (Hobbs and Gimingham 1984, 
Davies et al. 2010), where fire severities are high (Legg et al. 1992) or where there are compounded disturbances such as grazing and trampling by livestock (e.g. Legg et al. 1992). Understanding the consequences of wildfire for landscape carbon storage thus requires robust monitoring of post-fire vegetation regeneration. Assuming regeneration progresses communities back towards their pre-fire state, there are nevertheless substantial consequences of fire for carbon dynamics. Authors have provided contrasting data on dissolved organic carbon production and $\mathrm{CO}_{2}$ and $\mathrm{CH}_{4}$ fluxes and most of this information comes from low severity prescribed burns. Severe moorland wildfires have the potential to deliver large temperature pulses belowground, to remove insulating ground and surface fuel layers all of which may alter soil temperature (Figure 8), moisture, water table and microbial community dynamics. Previous authors (e.g. Worrall et al. 2007) have observed a raised water table in more frequently burnt sites and others were surprised to see reduced $\mathrm{CH}_{4}$ fluxes following burning (Ward et al. 2007) at the same site. Our results mirror those recorded by for methane by Ward et al. (2007), albeit for wild rather prescribed fires and for a wider range of sites. There is this increasing evidence for a decline in $\mathrm{CH}_{4}$ production in at least the first year following burning. Data on longerterm trends is now needed. Contrary to Ward et al. (2007), burning generally reduced $\mathrm{CO}_{2}$ fluxes for our sites. Differences between burnt and unburnt plots were, however, very small for two of our fires and $\mathrm{CO}_{2}$ production increased at Angelzarke. Our results suggest fire-related disturbance of microbial communities but identifying the underlying processes, and understanding site-to-site differences in response, will require further research. We also recorded substantial changes in diurnal soil temperature fluxes (Figure 8). Given that soil temperature is closely related to soil C flux (Updegraff et al. 2001) additional fine-temporal scale assessment of variation in $\mathrm{C}$ fluxes would be worthwhile. In conclusion our data show that drawing robust conclusions about the implications of wildfire on ecosystem $\mathrm{C}$ dynamics is fraught with difficulties. Characterising the effects of fuel consumption is made difficult by substantial variation in fuel structure between and within individual fires and the need to understand the nature of post-fire regeneration. Wildfires appeared to have substantial effects on soil ecological processes generally leading to reduced $\mathrm{CH}_{4}$ and $\mathrm{CO}_{2}$ fluxes. At this point it is difficult to determine whether this is due to the direct impacts of the fires themselves or associated changes in vegetation and soil microclimate. Key objectives of our on-going research include:

- Quantifying the relationship between carbon fluxes and fire (CBI) severity

- Modelling variation in carbon fluxes to differences in fire weather

- Describing how vegetation recovery varies as a function of fire severity

- Defining the mechanisms by which fuel structure and fire weather control fire severity (see Grau et al. this volume).

\section{Acknowledgements}

Thanks are due to Emily Taylor, Sophie Philbrick and Roger Grau for field and lab assistance. Julia McMorrow and the England \& Wales Wildfire Forum helped us obtain records of wildfires and our thanks go to all those who contributed data/information. We are particularly grateful to the owners and managers of the sites we used: Yorkshire Water, United Utilities, National Trust, Forestry Commission Scotland, Finzean Estate, Birse Community Trust, Bo Scholefield, Carl Prenton, Ian Harper, Kate Snow, Gemma Wren, Judith Patrick, Rob Soutar, Andrew Jarrott, Andrew Farquharson and Paul Chapman. This research was funded by the Natural Environment Research Council.

\section{References}

Bates D, Maechler M, Bolker B, Walker S (2013) lme4: Linear mixed-effects models using Eigen and S4. R package version 1.0-4. Available from: http://CRAN.R-project.org/package=lme4 [last accessed 15 Jul 2014]. 
Blodau C (2002) Carbon cycling in peatlands: a review of processes and controls. Environmental Reviews, 10 111-134.

Bullock JM, Webb NR (1995) Responses to severe fires in heathland mosaics in Southern England. Biological Conservation, 73, 207-214.

Clutterbuck B, Yallop AR (2010) Land management as a factor controlling dissolved organic carbon release from upland peat soils 2: changes in DOC productivity over four decades. Science of the Total Environment, 408, 6179-6191.

Davies GM (2006) Fire behaviour and impact on heather moorlands. PhD Thesis, The University of Edinburgh. Available from: https://www.era.lib.ed.ac.uk/handle/1842/2609 [last accessed $15 \mathrm{Jul}$ 2014].

Davies GM, Gray A, Hamilton A, Legg CJ (2008a) The future of fire management in the British uplands. International Journal of Biodiversity Science and Management, 4, 127-147.

Davies GM, Legg CJ, Hamilton A, Smith AA (2008b) Using visual obstruction to estimate heathland fuel load and structure. International Journal of Wildland Fire, 17, 380-389.

Davies GM, Legg CJ, Smith AA, McDonald AJ (2009) Rate of spread of fires in Calluna vulgarisdominated moorlands. Journal of Applied Ecology, 46, 1054-1063.

Davies GM, Smith AA, McDonald AJ, Bakker JD, Legg CJ (2010) Fire intensity, fire severity and ecosystem response in heathlands: factors affecting the regeneration of Calluna vulgaris. Journal of Applied Ecology, 47, 356-365.

Davies GM, Gray A, Rein G, Legg CJ (2013). Peat consumption and carbon loss due to smouldering wildfire in a temperate peatland. Forest Ecology and Management, 308, 136-144.

Dorrepaal E, Toet S, van Logtestijn RSP, Swart E, van de Weg MJ, Callaghan TV, Aerts R (2009) Carbon respiration from subsurface peat accelerated by climate warming in the subarctic. Nature, 460, 616-619.

Fernandes PM, Catchpole WR, Rego FC (2000) Shrubland fire behaviour modelling with microplot data. Canadian Journal of Forest Research, 30, 889-899.

Granström A, Schimmel J (1993) Heat effects on seeds and rhizomes of a selection of boreal forest plants and potential reaction to fire. Oecologia, 94, 307-313.

Hamilton A (2000) The characteristics and effects of management fire on blanket-bog vegetation in north-west Scotland. PhD Thesis, The University of Edinburgh.

Hobbs RJ, Gimingham CH (1984) Studies on fire in Scottish heathland communities II. Post-fire vegetation development. Journal of Ecology, 72, 585-610.

Holden J, Chapman PJ,Palmer SM, Kay P, Grayson R (2012) The impacts of prescribed moorland burning on water colour and dissolved organic carbon: a critical synthesis. Journal of Environmental Management, 101, 92-103.

Key CH, Benson NC (2006) Landscape Assessment (LA): Sampling and Analysis Methods. USDA Forest Service General Technical Report RMRS-GTR-164-CD. (Fort Collins, CO)

Kitchen K, Marno P, Legg C, Bruce M, Davies GM (2006) Developing a fire danger rating system for the UK. Forest Ecology and Management, 234, Supplement 1, S21.

Legg CJ, Maltby E, Proctor MCF (1992) The ecology of severe moorland fire on the North York Moors: seed distribution and seedling establishment of Calluna vulgaris. Journal of Ecology, 80, 737-752.

Legg CJ, Davies GM, Kitchen K, Marno P (2007) Developing a Fire Danger Rating System for the UK: FireBeaters Phase I final report. Report to the Scottish Wildfire Forum. Available from: https://www.era.lib.ed.ac.uk/handle/1842/3011 [last accessed 15 Jul 2014].

Legg CJ, Davies GM, Gray A (2010) Comment on "Burning management and carbon sequestration of upland heather moorland in the UK". Australian Journal of Soil Research, 48, 100-103.

Maltby E, Legg CJ, Proctor MCF (1990) The ecology of severe moorland fire on the North York Moors: effects of the 1976 fires, and subsequent surface and vegetation development. Journal of Ecology, 78, 490-518. 
Mitra S, Wassmann R, Vlek PLG (2005) An appraisal of global wetland area and its organic carbon stock. Current Science, 88, 25-35.

R Development Core Team (2012). R: A language and environment for statistical computing. (R Foundation for Statistical Computing, Vienna, Austria)

Schepers L, Haest B, Veraverbeke S, Spanhove T, Vanden Borre J, Goossens R (2014) Burned area detection and burn severity assessment of a heathland fire in Belgium using airborne imaging spectroscopy (APEX). Remote Sensing, 6, 1803-1826.

Smith AN, Thomas B (1956) The nutritive value of Calluna vulgaris IV. Digestibility at three, seven and fourteen years after burning. The Journal of Agricultural Science, 47, 468-475.

Tharme AP, Green RE, Baines D, Bainbridge IP, O'Brien M (2001) The effect of management for red grouse shooting on the population density of breeding birds on heather-dominated moorland. Journal of Applied Ecology, 38, 439-457.

Turetsky MT, Wieder K, Halsey L, Vitt D (2002) Current disturbance and the diminishing peatland carbon sink. Geophysical Research Letters, 29, 21-1-21-4.

Updegraff K, Bridgham SD, Pastor J, Weishampel P, Harth C (2001) Response of $\mathrm{CO}_{2}$ and $\mathrm{CH}_{4}$ emissions from peatlands to warming and water table manipulation. Ecological Applications, 11, 311-326.

Ward SE, Bardgett RD, McNamara NP, Adamson JK, Ostle NJ (2007) Long-term consequences of grazing and burning on northern peatland carbon dynamics. Ecosystems, 10, 1069-1083.

Worrall F, Armstrong A, Adamson JK (2007) The effects of burning and sheep-grazing on water table depth and soil water quality in a upland peat. Journal of Hydrology, 339, 1-14. 